\title{
Advances in surface passivation of c-Si solar cells
}

\author{
Mohammad Ziaur Rahman · Shahidul Islam Khan
}

Received: 4 June 2012/Accepted: 5 September 2012/Published online: 6 October 2012

(C) The Author(s) 2012. This article is published with open access at Springerlink.com

\begin{abstract}
In order to avoid an unacceptably large efficiency loss when moving towards thinner silicon materials, the near-term challenge in the c-Si PV industry is to implement an effective passivation method for both cell surfaces. This paper discussed several suitable passivation schemes available. While the efficiency potential of industrially produced thin film poly-Si cells on foreign substrates cannot yet reliably be predicted, it is clear that wafer-based c-Si solar cells will allow to maintain (or even improve) today's efficiency levels while at the same time reducing the consumption of (expensive) crystalline silicon by up to $50 \%$. Given the trend towards these Si materials, the most promising surface passivation methods are identified to date. The key issues to be considered are cost-effectiveness, added complexity, additional benefits, reliability, and efficiency potential. The efficiency increase for best cells is around 0.5-0.6\%abs and the current efficiency potential already demonstrated for all technologies is around $19.0 \%$. Average efficiencies in industrial mass production for selected technologies are 18.5-18.6\% for $\mathrm{Cz}$ and $17.1 \%$ for mc-Si.
\end{abstract}

Keywords Solar cell · Passivation - Emitter - Efficiency · $\mathrm{c}-\mathrm{Si}$

M. Z. Rahman ( $\square)$

Department of Electrical and Electronic Engineering,

Ahsanullah University of Science and Technology,

141-142 Love Road, Tejgaon I/A,

Dhaka 1208, Bangladesh

e-mail: ziaeee_083@yahoo.com

S. I. Khan

Department of Electrical and Electronic Engineering, Bangladesh University of Engineering and Technology, Dhaka 1000, Bangladesh

\section{Introduction}

The global photovoltaic (PV) market is booming over the years. Solar cell producers have to concentrate on the cost per watt peak $(\mathrm{Wp})$ of their product, especially as the competition between the manufacturers becomes more and more important. Therefore, most cell manufacturers try to optimize their solar cell processes concerning higher efficiencies while not significantly increasing costs. There are four different ways to improve c-Si solar cell efficiency:

- Increased light trapping effect by improving surface structuring and texturization.

- Redistributing the emitter profile on the front surface.

- Upgrading or changing metallization processes to get thinner contacts with excellent electrical properties.

- Optimizing the passivation layer on both surfaces to reduce the recombination losses.

This study focused on the present status of passivation of p-type c-Si solar cells with a special emphasis on passivation by $\mathrm{AL}_{2} \mathrm{O}_{3}$ due to its superiority over other passivation methods available.

The surface of c-Si represents the largest possible disturbance of the symmetry of the crystal lattice and hence, due to non-saturated ('dangling') bonds, a large density of defects ('surface states') within the bandgap exists at the surface of the crystal. These dangling bond defects can also be divided into intrinsic and extrinsic defects. There are typically additional processing-related extrinsic surface defects, for instance, due to dislocations or chemical residues and metallic depositions on the surface. These defects are highly prone to different recombination mechanisms, namely surface recombination, auger recombination and Shockley-Read-Hall (SRH) recombination (occurs via defects level within the bandgap) $[1,2]$. The recombination

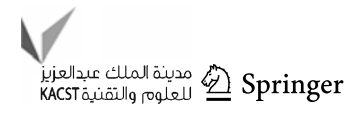


processes reduce the minority carrier life time and are responsible for lower conversion efficiency of $\mathrm{Si}$ solar cells. One way to keep the recombination loss at tolerable minimum is to passivate the silicon surfaces electronically $[3,4]$.

High-efficiency silicon solar cells require both surfaces (front and rear) to be well passivated. In this regard, electrical surface passivation of crystalline silicon (c-Si) solar cells has emerged as a key issue involving both conversion efficiency and fabrication cost. A low thermal budget $\left(\leq 400{ }^{\circ} \mathrm{C}\right)$ passivation technique that remains stable against ultraviolet photons of sunlight for longer period ( $>20$ years) is considered to be the more industrially convenient passivation technique.

In the following paragraphs, we will discuss the advances in surface passivation for high-efficiency c-Si solar cells.

\section{c-Si solar cell surface passivation techniques}

Surface passivation has become an essential factor for translating high-efficiency crystalline silicon solar cell concepts into industrial production schemes. In photovoltaics, a widespread method to determine the surface recombination is to measure the effective charge carrier lifetime from the photoconductance of symmetrically passivated silicon wafers in transient or quasi-static mode [5]. An excellent electrical interface quality is essential for many devices relying on the bulk electronic properties of semiconductors [6]. Electrical losses at a semiconductor interface or surface should be minimized in photonic devices based on group III-V or group IV semiconductors when radiative recombination should be the dominant process [7, 8]. Moreover, electronic losses at the crystalline $\mathrm{Si}$ (c-Si) surface have become increasingly important in the field of c-Si solar cells due to the trend toward thinner c-Si wafers used as base material. Consequently, the reduction of recombination losses at semiconductor interfaces is a prime concern for numerous semiconductor applications.

Recombination losses at a semiconductor interface or surface can be reduced by two different passivation strategies. As the recombination rate is directly proportional to the interface defect density, the first strategy is based on the reduction in the number of defect states at the interface. The interface defect density can be reduced significantly by the passivation of under coordinated atoms (dangling bonds) by, e.g., atomic $\mathrm{H}$ or by a thin dielectric or semiconductor film. This strategy is commonly referred to as chemical passivation. For example, the midgap interface defect density of c-Si can be as low as $1 \times 10^{9} \mathrm{eV}^{-1} \mathrm{~cm}^{-2}$ after the growth of a high-quality thermal $\mathrm{SiO}_{2}$ film and a subsequent alneal in a $\mathrm{H}_{2}$ atmosphere, e.g., a FGA [9].
The second strategy to reach surface passivation is based on a significant reduction of the electron or hole concentration at the semiconductor interface by means of a builtin electric field. As recombination processes require both electrons and holes, the highest recombination rate is obtained when the electron and hole concentration at the interface are approximately equal in magnitude (assuming identical capture cross sections for electrons and holes). In other cases the recombination rate scales with the minority carrier concentration at the surface. In the so-called fieldeffect passivation, the electron or hole concentration at the semiconductor interface is altered by electrostatic shielding of the charge carriers through an internal electric field present at the interface. This internal electric field can either be obtained by a doping profile below the interface or by the presence of fixed electrical charges at the semiconductor interface. Consequently, the application areas of field-effect passivation are limited, but the effect can be employed successfully in devices such as light emitting diodes and solar cells [10].

There are two fundamentally different types of surfaces in a c-Si solar cell: metallized and non-metallized surfaces. Metal silicon interfaces feature very high SRVs and hence need to be carefully designed to avoid excessively large recombination losses. Similarly, to ensure a good blue response of the cell, the illuminated non-metallized surface regions need to be well passivated and not too heavily doped to avoid the formation of a dead layer. In the case of laboratory c-Si cells, the importance of the passivation of both cell surfaces is well recognized.

\section{Fundamental theory of surface recombination}

The surfaces or interfaces of a silicon substrate represent a severe discontinuity in its crystalline structure. The large numbers of partially bonded silicon atoms give rise to many dangling bonds, and therefore, a large density of defect levels are found within the bandgap near the semiconductor surface. Even if the silicon surface is not bare, say due to a native oxide, the presence of silicon-oxygen bonds can strain the crystal structure at the surface, which again introduces many defect states.

For a single defect at the surface, the rate of surface recombination, $U_{s}$ is given by [11]

$U_{\mathrm{s}}=\frac{n_{\mathrm{s}} p_{\mathrm{s}}-n_{i}^{2}}{\frac{n_{\mathrm{s}}+n_{1}}{S_{p 0}}+\frac{p_{\mathrm{s}}+p_{1}}{S_{n 0}}}$

where $n_{\mathrm{s}}$ and $p_{\mathrm{s}}$ are the concentrations of electrons and holes at the surface, and $S_{p 0}$ and $S_{n 0}$ are related to the density of surface states per unit area, $N_{t s}$, the capture cross-sections, $\sigma_{n}$ and $\sigma_{p}$, and thermal velocity, $v_{t h}$ for the specific defect 
$S_{n 0} \equiv \sigma_{n} v_{t h} N_{t s} \quad$ and

$S_{p 0} \equiv \sigma_{p} v_{t h} N_{t s}$

In reality, defect levels are so numerous that they can be considered to be continuously distributed throughout the bandgap, and both their density and capture cross-sections will be dependent on their energy level.

Similar to the definition of the recombination lifetime $\left(\tau(\Delta n)=\frac{\Delta n}{U(\Delta n)}\right)$, the surface recombination velocity, $S$ is defined as

$U_{\mathrm{s}} \equiv S \Delta n_{\mathrm{s}}$

where $\Delta n_{\mathrm{s}}$ is the excess carrier density at the surface.

Hence, the surface recombination velocity can be related to the fundamental properties of the surface defects through (3). For the case of flatband conditions at the surface and negligible carrier trapping, the excess densities of electrons and holes are equal $\left(\Delta n_{\mathrm{s}}=\Delta p_{\mathrm{s}}\right)$, giving [3]

$S\left(\Delta n_{\mathrm{s}}\right)=\frac{n_{0}+p_{0}+\Delta n_{\mathrm{s}}}{\frac{n_{0}+n_{1}+\Delta n_{\mathrm{s}}}{S_{p 0}}+\frac{p_{0}+p_{1}+\Delta n_{\mathrm{s}}}{S_{n 0}}}$

It is the surface recombination velocity, $S$, that is typically used for quantifying surface recombination processes. In general, the surface passivation is controlled by the reduction of interface defect states (chemical passivation) and by shielding of minority charge carriers from the surface (fieldeffect passivation). This is illustrated in Eq. 1. The driving force of the surface recombination process is the term $\left(n_{\mathrm{s}} p_{\mathrm{s}}-n_{i}^{2}\right)$ which describes the deviation of the system from the thermal equilibrium under illumination. The relative importance of either chemical passivation or field-effect passivation depends on the passivation scheme used.

Front surface passivation

Front surface passivation was attained with thermal $\mathrm{SiO}_{2}$ and $\mathrm{TiO}_{2}$ fabricated by atmospheric chemical vapor deposition. Thermal growth of silicon oxide is the most effective c-Si surface passivation technique for solar cell, but this technique is not suitable for low-cost industrial processes as it requires very high temperature (above $1,000{ }^{\circ} \mathrm{C}$ ) treatment. High temperature degrades the bulk life time significantly as well as the stability of passivated surface [12]. Moreover, $\mathrm{SiO}_{2}$ has very low refractive index which is not suitable for good antireflection performance. On the other hand, $\mathrm{TiO}_{2}$ does not provide any electronic surface passivation. In the past two decades, various research efforts have been devoted to the development of a more industrially convenient solution, in particular, on passivation layers deposited at low temperature $\left(\leq 400{ }^{\circ} \mathrm{C}\right)$ onto the c-Si surface. $\mathrm{SiN}_{x}$ front side passivation using plasma-enhanced chemical vapor deposition (PECVD) has been evolved as an alternative to high-temperature oxidation of silicon [13-15]. Record low effective surface recombination velocity (SRV) of $4 \mathrm{~cm} / \mathrm{s}$ has been obtained on $1 \Omega \mathrm{cm}$ p-Si wafers for $\mathrm{SiN}_{x}$ using remote PECVD or high-frequency $(13.56 \mathrm{MHz})$ direct PECVD [14]. $\operatorname{SiN}_{x}$ passivation for front surface of c-Si solar cells is deemed to be superior over other passivation techniques such as $\mathrm{SiO}_{2}$, $\mathrm{TiO}_{2}$, etc. due to its (1) field effect passivation provided by positive interface charges, (2) properties of capture crosssections of dominant defects, (3) adjustable refractive index as antireflection coating (ARC) and (4) hydrogenated passivation of bulk defects $[3,12,16,17]$.

\section{Rear surface passivation}

Usage of thinner wafers and an effective reduction of surface recombination losses are increasingly important for low-cost highly efficient silicon solar cells. Hence the recent trend in silicon-wafer-based PV industries is toward thinner wafers $(<200 \mu \mathrm{m})$. But the use of thinner wafers increases the rear surface recombination [12] and consequently necessitates a well-passivated rear surface to keep the rear surface recombination loss in acceptable minimum. Moreover, the increasing demands for optical quality require a higher internal reflection as well. Therefore, all designs for high-efficiency silicon solar cells today use a dielectric passivation layer on the rear to meet the requirements of passivation quality and optical properties. Keeping in mind the above attributes a good number of rear surface passivation techniques were developed over the years; among them atomic layer deposition (ALD)-assisted $\mathrm{Al}_{2} \mathrm{O}_{3}$, wet oxidation process using pyrogenic steam, passivation by stack of a- $\mathrm{Si}: \mathrm{H} / \mathrm{SiO}_{2}$ or $\mathrm{Al}_{2} \mathrm{O}_{3} / \mathrm{SiN}_{x}$ and passivation by phosphorus-doped a- $\mathrm{SiC}_{x} \mathrm{~N}_{y}: \mathrm{H}(n)$ alloys are the most notable rear side passivation techniques for crystalline silicon solar cells. Recent research results on these rear surface passivation techniques are aggregated below.

\section{Rear passivation by $\mathrm{Al}_{2} \mathrm{O}_{3}$}

In the case of mc-Si wafers, thermal processes above $900{ }^{\circ} \mathrm{C}$ typically lead to a significant degradation of bulk lifetime [18]. $\mathrm{Al}_{2} \mathrm{O}_{3}$ rear passivation by $\mathrm{ALD}$ has been evolved as an alternative of low-temperature surface passivation for high-efficiency silicon solar cells which have comparable properties as that of the alnealed $\mathrm{SiO}_{2}$ [19-24]. The excellent level of surface passivation by $\mathrm{Al}_{2} \mathrm{O}_{3}$ films is reflected by SRVs $<5 \mathrm{~cm} / \mathrm{s}$ for low-resistivity p-type c-Si, after alnealing at $400{ }^{\circ} \mathrm{C}$ in $\mathrm{N}_{2}$ [22, 25-27]. A detailed study on ALD deposited $\mathrm{Al}_{2} \mathrm{O}_{3}$ has been reported by Schmidt et al. [28].

Recently, it was demonstrated that an exceptional high level of c-Si surface passivation can be achieved for $\mathrm{SiO}_{2}$ 
synthesized at low temperatures when combined with a very thin $\mathrm{Al}_{2} \mathrm{O}_{3}$ capping film [29]. The passivation was virtually independent of the $\mathrm{SiO}_{2}$ thickness and showed an exceptional firing stability. $C-V$ measurements revealed that the $\mathrm{SiO}_{2} / \mathrm{Al}_{2} \mathrm{O}_{3}$ stacks yielded a high level of chemical passivation after alnealing due to a low interface defect density. Preliminary results using an alternative method to synthesize the low-temperature $\mathrm{SiO}_{2}$ films, and (similar) results for thermally grown $\mathrm{SiO}_{2}$ [30], have suggested that the effective hydrogenation under influence of the $\mathrm{Al}_{2} \mathrm{O}_{3}$ capping film may be general. Moreover, preliminary data on the long-term stability showed a low $S_{\text {eff }}(<4 \mathrm{~cm} / \mathrm{s})$ for a stack measured after 250 days. The excellent efficiency values (up to $21.3-21.5 \%$ ), the high voltages $(680 \mathrm{mV})$, the excellent long-wavelength quantum efficiency, and the high short-circuit currents of these cells $\left(40 \mathrm{~mA} / \mathrm{cm}^{2}\right)$ are a proof for the low rear-SRV and excellent internal rearsurface reflection [31]. Moreover, $\mathrm{Al}_{2} \mathrm{O}_{3}$ passivation overcomes the so-called 'parasitic shunting' effects which is very common for $\mathrm{SiN}_{x}$ passivated rear [32]. Low-temperature-synthesized $\mathrm{SiO}_{2} / \mathrm{Al}_{2} \mathrm{O}_{3}$ passivation schemes can provide a realistic alternative for thermally grown $\mathrm{SiO}_{2}$ in next-generation solar cells.

The key differentiator of $\mathrm{Al}_{2} \mathrm{O}_{3}$ in comparison with other passivation schemes is its high fixed negative charge density $Q_{\mathrm{f}}\left(10^{12}-10^{13} \mathrm{~cm}^{-2}\right)$ located at the $\mathrm{Al}_{2} \mathrm{O}_{3} / \mathrm{Si}$ interface which produces effective field-effect passivation by shielding electrons from the interface [33-35]. The origin of the negative $Q_{\mathrm{f}}$ in $\mathrm{Al}_{2} \mathrm{O}_{3}$ deposited on c-Si has been attributed to intrinsic and extrinsic defects in $\mathrm{Al}_{2} \mathrm{O}_{3}$. Matsunaga et al. [36] calculated the energetics of intrinsic vacancies and interstitials in $\mathrm{Al}_{2} \mathrm{O}_{3}$ from first principles. These calculations showed that each intrinsic point defect is most stable in their fully ionized form. Hence, $\mathrm{Al}$ vacancies and $\mathrm{O}$ interstitials exhibit a negative charge and $\mathrm{Al}$ interstitials and $\mathrm{O}$ vacancies exhibit a positive charge in good agreement with the ionic nature of the $\mathrm{Al}_{2} \mathrm{O}_{3}$ [36]. Extrinsic $\mathrm{H}$ has also been proposed as origin for the negative fixed charges in $\mathrm{Al}_{2} \mathrm{O}_{3}$. Peacock and Robertson [37] calculated that interstitial $\mathrm{H}$ acts as a deep trap site for electrons in $\mathrm{Al}_{2} \mathrm{O}_{3}$. $\mathrm{H}$ is, for example, a common constituent in $\mathrm{Al}_{2} \mathrm{O}_{3}$ synthesized by ALD because $\mathrm{H}$-containing precursors such as $\mathrm{Al}\left(\mathrm{CH}_{3}\right)_{3}$ and $\mathrm{H}_{2} \mathrm{O}$ are used in the deposition process. Hence, $\mathrm{Al}$ vacancies, $\mathrm{O}$ interstitials, and interstitial $\mathrm{H}$ are proposed as the origin of the negative $Q_{\mathrm{f}}$ in $\mathrm{Al}_{2} \mathrm{O}_{3}$. Based on the ionic nature of $\mathrm{Al}_{2} \mathrm{O}_{3}$, Lucovsky [38] postulated that $\mathrm{Al}_{2} \mathrm{O}_{3}$ consists of tetrahedrally coordinated $\mathrm{Al}$ in $\mathrm{AlO}_{4-}$ units and octahedrally coordinated $\mathrm{Al}_{3+}$ in a ratio of $3: 1$ to assure charge neutrality. Kimoto et al. [39] demonstrated that both tetrahedrally and octahedrally coordinated $\mathrm{Al}$ are present in $\mathrm{Al}_{2} \mathrm{O}_{3}$ grown by thermal ALD on H-terminated c-Si. However, tetrahedrally coordinated $\mathrm{Al}$ was found to be dominant at the interface.
This dominance was attributed to the fact that $\mathrm{Si}$ in the interfacial $\mathrm{SiO}_{x}$ film also has a tetrahedral coordination [39]. Consequently, the interfacial $\mathrm{SiO}_{x}$ film could fulfill an important role in the origin of the negative $Q_{\mathrm{f}}$ that is found in $\mathrm{Al}_{2} \mathrm{O}_{3}$ films grown on c-Si by inducing a high-density of negatively charged $\mathrm{Al}$ vacancies close to the interface. This hypothesis is in good agreement with the location of the negative $Q_{\mathrm{f}}$ extracted from thickness-dependent $C-V$ measurements by various authors [40-42].

The $\mathrm{Al}_{2} \mathrm{O}_{3}$ passivation mechanism has been elucidated by contactless characterization of $\mathrm{c}-\mathrm{Si} / \mathrm{Al}_{2} \mathrm{O}_{3}$ interfaces by optical second-harmonic generation (SHG). SHG has revealed a negative fixed charge density in $10^{11} \mathrm{~cm}^{-2}$ that increased to as-deposited $\mathrm{Al}_{2} \mathrm{O}_{3}$ on the order of $10^{12}$ $10^{13} \mathrm{~cm}^{-2}$ upon alnealing, causing effective field-effect passivation. In addition, multiple photon-induced charge trapping dynamics suggest a reduction in recombination channels after alneal and indicate a c-Si/ $\mathrm{Al}_{2} \mathrm{O}_{3}$ conduction band offset of $2.02 \pm 0.04 \mathrm{eV}$ [43]. This makes $\mathrm{Al}_{2} \mathrm{O}_{3}$ especially suited for the passivation of p-type silicon and $\mathrm{p}+$ emitters, while $\mathrm{Al}_{2} \mathrm{O}_{3}$ is expected to be less suitable for n-type (due to parasitic shunting) and $n+$ type silicon (yet this still remains to be proven). The thermal stability of $\mathrm{Al}_{2} \mathrm{O}_{3}$ during firing and the low-temperature deposition of the films are compatible with industrial solar cell processes [44]. $\mathrm{Al}_{2} \mathrm{O}_{3}$ is transparent (bandgap $\sim 9 \mathrm{eV}$ ) and stable under UV illumination [45, 46], but the refractive index of $\sim 1.64$ makes it less suitable for single layer ARC on the front side as compared with $a-\mathrm{SiN}_{x}$. As a back reflector, however, $\mathrm{Al}_{2} \mathrm{O}_{3}$ is superior. Also the fact that very thin $\mathrm{Al}_{2} \mathrm{O}_{3}$ films (down to $5 \mathrm{~nm}$ ) can be used is another benefit of $\mathrm{Al}_{2} \mathrm{O}_{3}$ and enables flexibility in the design of surface passivation schemes and stacks [47]. As a consequence of these (unique) properties, $\mathrm{Al}_{2} \mathrm{O}_{3}$ is now considered an important candidate for surface passivation in industrial solar cells, either for front and/or rear side passivation. A remaining challenge in this respect is the development of deposition tools for $\mathrm{Al}_{2} \mathrm{O}_{3}$ films compatible with the requirements, especially in terms of throughput, of the solar cell industry [48, 49].

\section{Wet oxidized rear passivation}

A wet oxidation process using pyrogenic steam at $800{ }^{\circ} \mathrm{C}$ has been applied on $250 \mu \mathrm{m}$ thick boron-doped $(0.5 \Omega \mathrm{cm})$ high-quality float zone (FZ) silicon to study its suitability for rear side passivation at Fraunhofer ISE [50, 51]. In the long-wavelength region of incident photons, this wet oxidized rear passivation has high internal reflectance which leads to an absolute gain of $6 \%$ in both $J_{\mathrm{sc}}$ and $V_{\mathrm{oc}}$ compared with Al-back surface field (BSF) cells though there is about $3 \%$ absolute loss in FF due to increase in series resistance for point-contacts [52]. 
Wet oxides grown from purified steam have been demonstrated to provide a high level of surface passivation that at least is comparable to wet oxides grown by the standard process, where the water vapor is introduced by the pyrolytic generation from high-purity gases $\left(\mathrm{H}_{2}, \mathrm{O}_{2}\right)$ [53]. The rear side of laboratory type laser-fired contact (LFC) solar cells has been passivated by a wet oxide grown from purified steam at a temperature of $850{ }^{\circ} \mathrm{C}$. As a reference also a standard wet oxide grown at the same temperature as well as a dry oxide grown at $1,050{ }^{\circ} \mathrm{C}$ has been applied for the passivated emitter rear cell (PERC) type solar cells. For all cells, conversion efficiencies well above $20 \%$ could be reached. The average open-circuit voltages for the different rear side passivation layers lie in a very close range of $648.4 \mathrm{mV}$ for the wet oxide grown from purified steam to $650.6 \mathrm{mV}$ for the dry oxidation. The rear SRV that was extracted from the measured quantum efficiency for all oxides is in the range of $80-100 \mathrm{~cm} / \mathrm{s}$. Thus, the wet oxides grown from purified steam seem to be well suited for the rear side passivation of PERC-type solar cells. The one-sun parameters of the PERC-type solar cells featuring the rear side passivation by the different dry and wet thermal oxides are summarized in Table 1.

In addition, this wet oxidation process has about one order of magnitude faster growth rate than the traditional high-temperature $\left(1,050{ }^{\circ} \mathrm{C}\right)$ dry oxidation process and can close the gap between laboratory and industrial application by overcoming the longer high thermal budget of dry oxidation [54].

Rear passivation by stack of a-Si:H/SiO $\mathrm{Si}_{2}$

A PECVD double layer of amorphous silicon-rich oxynitride and amorphous silicon nitride $\left(\mathrm{SiN}_{x}\right)$ can provide a nearly perfect passivation after subsequent rapid thermal process (RTP) and light soaking. The resulting effective minority carriers' lifetime $\left(\tau_{\text {eff }}\right)$ is close to the modeled maximum on p-type as well as on n-type c-Si. Restrictions on the RTP of passivated surfaces, typical of other common passivation schemes (e.g., amorphous $\mathrm{Si}$ ), are relieved by this double layer. Harsher thermal treatments can be adopted while still obtaining salient passivation. It is shown that the strong quality of surface passivation is ensured by a mechanism that emits electrons from shallow donor states in the passivation layer system and therefore creates a positive field effect [55].

Very low SRVs $<6$ and $<11 \mathrm{~cm} / \mathrm{s}$ were obtained for $\mathrm{SiO}_{x} / a-\mathrm{SiN}_{x}: \mathrm{H}$ stacks synthesized by PECVD on lowresistivity $\mathrm{n}$ - and $\mathrm{p}$-type $\mathrm{c}-\mathrm{Si}$, respectively. The stacks induced a constant effective lifetime under low illumination, comparable to $\mathrm{Al}_{2} \mathrm{O}_{3}$ on p-type $\mathrm{Si}$. Compared with single layer $a$-SiN $x: \mathrm{H}$, a lower positive fixed charge density was revealed by SHG measurements, while field-effect passivation was absent for a reference stack comprising thermally grown $\mathrm{SiO}_{2}$. The results indicate that hydrogenation of interface states played a key role in the passivation and remained effective up to alnealing temperatures $>800{ }^{\circ} \mathrm{C}$ [56]. The best achieved energy conversion efficiency of $21.7 \%$ for c-Si solar cells (that was confirmed by the Fraunhofer ISE CalLab) was reported in [57, 58].

Passivation by phosphorus-doped $\mathrm{a}-\mathrm{SiC}_{x} \mathrm{~N}_{y}: \mathrm{H}(n)$ alloys

Amorphous silicon nitride $\left(\mathrm{a}-\mathrm{SiN}_{x}: \mathrm{H}\right)$ deposited by PECVD was considered as the most feasible alternative to thermally grown silicon oxide on c-Si surface due to its ability to serve as both passivation and anti-reflection coating. Recently, a study conducted on amorphous silicon carbide $\left(\mathrm{a}-\mathrm{SiC}_{x}: \mathrm{H}\right)$ proved that it could be the best alternative to a-SiN $\mathrm{S}_{x}: \mathrm{H}$ since its optical characteristics can be tuned by the carbon content of the film [14, 59].

Phosphorus-doped amorphous silicon carbide $\left(\mathrm{a}-\mathrm{SiC}_{x}\right.$ : $\mathrm{H}(n))$ demonstrated the ability to passivate p-type c-Si substrates and highly doped n-type emitters in solar cells [60-63]. Hydrogenated amorphous silicon carbide (a-SiC:H) provides excellent electronic surface passivation for crystalline silicon solar cells. The hydrogen and carbon content of the passivation layers control the surface passivation depending on hydrogen bonding and alnealing temperature $[64,65]$. The carbon content $\mathrm{C}_{\mathrm{c}}$ of the amorphous layers varies depending on the methane-to-silane gas flow ratio during deposition. The electronic passivation quality exhibits best thermal stability for an optimum $\mathrm{C}_{\mathrm{c}}=2.3$ at. $\%$. Alnealing this sample under forming gas atmosphere up to $\mathrm{TFG}=550{ }^{\circ} \mathrm{C}$ enables excellent effective minority carrier lifetimes of $1.2 \mathrm{~ms}$ [66]. Hydrogen effusion measurements relate this result to an increase in $\mathrm{H}$-content with rising $\mathrm{C}_{\mathrm{c}}$ and to a simultaneous shift of the

Table 1 One-sun parameter (best values) and surface recombination velocity, SRV of LFC solar cells with different rear surface passivations: (1) dry $\mathrm{SiO}_{2}$, (2) wet $\mathrm{SiO}_{2}$ (purified steam), (3) wet $\mathrm{SiO}_{2}$ (pyrolytic generation of water vapor)

\begin{tabular}{|c|c|c|c|c|c|}
\hline & $V_{\text {oc }}(\mathrm{mV})$ & $J_{\mathrm{sc}}\left(\mathrm{mA} / \mathrm{cm}^{2}\right)$ & $\mathrm{FF}(\%)$ & $\eta(\%)$ & $\mathrm{SRV}(\mathrm{cm} / \mathrm{s})$ \\
\hline Dry Oxidation $\left(1,050{ }^{\circ} \mathrm{C}, 97 \mathrm{~nm}\right)$ & 652.4 & 39.9 & 80.5 & 21 & 90 \\
\hline Wet oxidation, purified steam $\left(850^{\circ} \mathrm{C}, 110 \mathrm{~nm}\right)$ & 650.7 & 40.1 & 79.1 & 20.6 & 80 \\
\hline Wet oxidation, pyrolytic generation $\left(850^{\circ} \mathrm{C}, 95 \mathrm{~nm}\right)$ & 651.7 & 39.9 & 80.5 & 20.9 & 100 \\
\hline
\end{tabular}


effusion peaks to higher temperatures [65, 67]. Higher carbon content reduces the diffusion of atomic hydrogen out of the amorphous layers. The $\mathrm{Si}-\mathrm{H}$ bonding configurations in the amorphous layers, analyzed from infrared absorption spectroscopy, reveal that a-SiC:H layers with lower carbon content have a higher density. Increasing $\mathrm{C}_{\mathrm{c}}$ induces voids and microvoids in the amorphous structure, favoring the diffusion of molecular hydrogen out of the a-SiC:H layers [68, 69].

Very silicon-rich films yielded effective SRVs at 1 sunillumination as low as 3 and $2 \mathrm{~cm} \mathrm{~s}^{-1}$ on $1 \Omega \mathrm{cm} \mathrm{p}$ - and n-type crystalline silicon substrates, respectively [70]. An efficiency of $20.2 \%$ was reported for PERC following the approach in [34, 63]. The reported values had been obtained without forming gas alneal (FGA) and the stability in surface passivation had been verified for a 2-month period. Such stacks have the additional benefit of being more dielectric than silicon-rich films, thus avoiding the degradation of field effect passivation due to shunting effects [32]. This result demonstrates that $\mathrm{a}-\mathrm{SiC}_{x} \mathrm{~N}_{y}$ : $\mathrm{H}(n)$ films can be useful for designing high-efficiency c-Si solar cells.

\section{Passivation by $\mathrm{Al}_{2} \mathrm{O}_{3} / \mathrm{SiN}_{x}$-layer stack}

Despite the merits of $\mathrm{Al}_{2} \mathrm{O}_{3}$, it was shown that the samples which are passivated by a single layer of $\mathrm{Al}_{2} \mathrm{O}_{3}$ without the protecting $\mathrm{SiN}_{x}$ layer show a largely destroyed $\mathrm{Al}_{2} \mathrm{O}_{3}$ layer after metallization etch-back [71]. Investigations on lifetime samples showed a 2.5-fold increase in effective lifetime and an efficiency gain of $0.7 \%$ absolute (max. efficiency $18.6 \%$ ) for surfaces passivated by an $\mathrm{Al}_{2} \mathrm{O}_{3}$ / $\mathrm{SiN}_{x}$ stack compared with fully metallized Al-BSF rear sides. An increase in the infrared spectrum of the internal quantum efficiency is determined as the source of this gain. However, this cell exhibited a reduction in $\mathrm{FF}$ due to an increase in series resistance locally. For $\mathrm{Al}_{2} \mathrm{O}_{3}$ and $\mathrm{Al}_{2} \mathrm{O}_{3}$ / a-SiN $\mathrm{S}_{x}: \mathrm{H}$ stacks on $2 \Omega \mathrm{cm}$ n-type c-Si, ultralow SRVs of $S_{\text {eff }}<3 \mathrm{~cm} / \mathrm{s}$ were obtained and the passivation proved sufficiently stable $\left(S_{\text {eff }}<14 \mathrm{~cm} / \mathrm{s}\right)$ against a high-temperature "firing" process $\left(>800{ }^{\circ} \mathrm{C}\right)$ used for screen printed c-Si solar cells [72].

\section{Discussion and outlook}

Surface recombination is very effectively suppressed by means of silicon dioxide $\left(\mathrm{SiO}_{2}\right)$ grown in a high-temperature $\left(\geq 900{ }^{\circ} \mathrm{C}\right)$ oxidation process. Very low SRVs are in particular realized at the lightly doped rear surface, where the combination of a thermally grown $\mathrm{SiO}_{2}$ layer with an evaporated film of $\mathrm{Al}$ give - after an additional alnealing treatment at $400{ }^{\circ} \mathrm{C}$ (the so-called 'alneal') - SRVs below
$20 \mathrm{~cm} / \mathrm{s}$ on un-metallized low-resistivity $(\sim 1 \Omega \mathrm{cm})$ p-type silicon wafers. In addition, the $\mathrm{SiO}_{2} / \mathrm{Al}$ stack at the cell rear acts as an excellent reflector for near bandgap photons, significantly improving the light-trapping properties and hence the short-circuit current of the cell.

One of the main reasons why high-temperature oxidation has not been implemented into the majority of industrial cell processes up to now is the high sensitivity of the silicon bulk lifetime to high-temperature processes. In particular in the case of multi-crystalline silicon wafers, thermal processes above $900{ }^{\circ} \mathrm{C}$ typically lead to a significant degradation of the bulk lifetime. Hence, low-temperature surface passivation alternatives are required for future industrial high-efficiency silicon solar cells, which should have comparable properties as the alnealed $\mathrm{SiO}_{2}$.

One intensively investigated low-temperature surface passivation alternative to thermal oxide is silicon nitride $\left(\mathrm{SiN}_{x}\right)$ grown by PECVD at $\sim 400{ }^{\circ} \mathrm{C}$, which has proven to give comparably low SRVs as thermal $\mathrm{SiO}_{2}$ on low-resistivity p-type silicon [14, 73]. However, when applied to the rear of passivated emitter and rear cell (PERC)-type solar cells the short-circuit current density is strongly reduced compared with the $\mathrm{SiO}_{2}$-passivated cell rear [74]. This effect has been attributed to the large density of fixed positive charges within the $\mathrm{SiN}_{x}$ layer, inducing an inversion layer in the crystalline silicon underneath the $\operatorname{SiN}_{x}$. The coupling of this inversion layer to the base contact leads to a significant loss in the short-circuit current density. This detrimental effect is known as 'parasitic shunting' [32]. Another alternative low-temperature passivation scheme resulting in comparable $\mathrm{SRVs}$ as alnealed $\mathrm{SiO}_{2}$ is intrinsic hydrogenated amorphous silicon (a-Si) deposited by PECVD in the temperature range between 200 and $250{ }^{\circ} \mathrm{C}$ [75]. Despite the fact that no parasitic shunting occurs in the case of a-Si passivated cell rear, new problems arise from the high sensitivity of the a-Si passivation to thermal processes. More recently, it was shown that thin films of aluminum oxide $\left(\mathrm{Al}_{2} \mathrm{O}_{3}\right)$ grown by ALD provide an excellent level of surface passivation on lowly doped $(\sim 1 \Omega \mathrm{cm})$ p- and n-type silicon wafers [25, 28, 76] as well as on highly boron-doped $\mathrm{p}+$ emitters [75].

Figure 1 shows a comparison of the injection dependent effective SRVs measured on 1-2 $\Omega \mathrm{cm}$ p-type silicon wafers passivated by (1) $\mathrm{SiN}_{x}$ deposited by remote- PECVD [78], (2) intrinsic a-Si deposited in a parallel-plate PECVD reactor [75], and (3) $\mathrm{Al}_{2} \mathrm{O}_{3}$ deposited by means of plasma-assisted ALD [79]. The measurements are shown in the injection range between $10^{12}$ and $10^{15} \mathrm{~cm}^{-3}$, which is the most relevant range for the rear of one-sun silicon solar cells. Within this injection range it becomes obvious from Fig. 1 that the $\mathrm{Al}_{2} \mathrm{O}_{3}$ passivation outperforms the welloptimized $\mathrm{SiN}_{x}$ as well as the a-Si passivation. Importantly, the $\mathrm{Al}_{2} \mathrm{O}_{3}$ passivation results in a very weak injection-level 


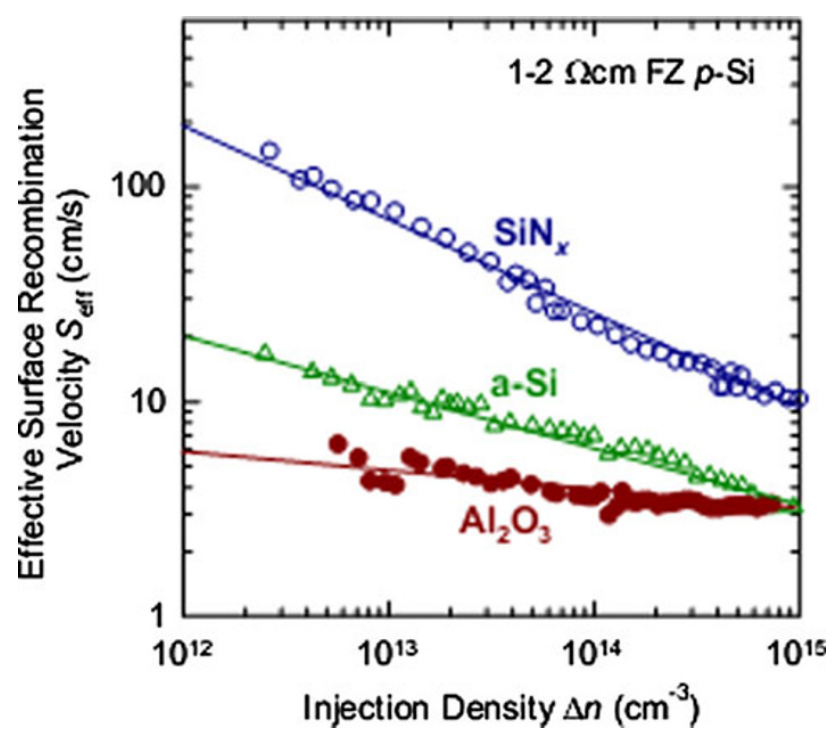

Fig. 1 Comparison of the injection-dependent effective SRVs $S_{\text {eff }}$ $(\Delta n)$ measured on 1-2 $\Omega \mathrm{cm}$ p-type floatzone silicon wafers passivated by (1) $\mathrm{SiN}_{x}$ deposited by remote-PECVD [78], (2) intrinsic a-Si deposited in a parallel-plate PECVD reactor [75] and (3) $\mathrm{Al}_{2} \mathrm{O}_{3}$ deposited by means of plasma-assisted ALD [79]. The lines are guides to the eye

dependence in the injection range between $10^{12}$ and $10^{15} \mathrm{~cm}^{-3}$, and the effective SRV stays well below $10 \mathrm{~cm} / \mathrm{s}$ even at low injection densities $<10^{13} \mathrm{~cm}^{-3}$. The strong injection-level dependence of the effective SRV measured on $\mathrm{SiN}_{x}$-passivated $\mathrm{p}$-Si surfaces can be attributed to recombination within the space charge region induced by the high fixed positive charge density within the $\mathrm{SiN}_{x}$ layer [73].

Figure 2 shows the measured effective SRV as a function of the corona charge density deposited onto dielectric passivation layers of $\mathrm{SiN}_{x}$ and $\mathrm{Al}_{2} \mathrm{O}_{3}$. In the flatband case when the deposited Corona charge density equals the fixed charge density within the dielectric layer, the recombination rate shows a maximum. From this maximum the charge density within the layer can be deduced. As can be seen from Fig. 2, the fixed charge density within the $\mathrm{SiN}_{x}$ layer is positive and amounts to $Q_{\mathrm{f}}=+2 \times 10^{12}$ elementary charges $/ \mathrm{cm}^{2}$, whereas the fixed charge density within the $\mathrm{Al}_{2} \mathrm{O}_{3}$ layer is negative and amounts to $Q_{\mathrm{f}}=-1.3 \times 10^{13} \mathrm{~cm}^{-2}$. The fixed negative charge density within the $\mathrm{Al}_{2} \mathrm{O}_{3}$ layer induces an accumulation layer at the p-type silicon surface in contrast to the $\mathrm{SiN}_{x}$ layer inducing and inversion layer. As a consequence, the $\mathrm{Al}_{2} \mathrm{O}_{3}$ provides a very effective field-effect passivation without the additional contribution of recombination in the space charge region, which is the dominant recombination channel in the case of the $\mathrm{SiN}_{x}$ passivation of p-type silicon surfaces at low injection densities [73, 77]. In addition, due to the formation of an accumulation layer instead of an

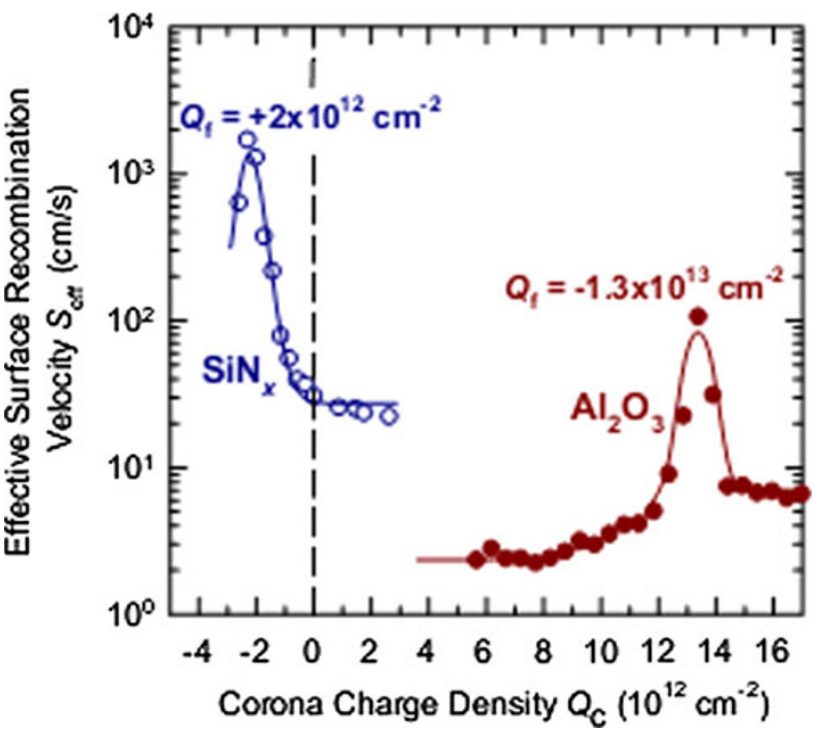

Fig. 2 Measured effective SRV $S_{\text {eff }}$ as a function of the corona charge density $Q_{\mathrm{C}}$ deposited onto dielectric passivation layers of $\mathrm{SiN}_{x}$ and $\mathrm{Al}_{2} \mathrm{O}_{3}$. The lines are guides to the eye

inversion layer at the p-type silicon surface, the abovementioned parasitic shunting effect at the solar cell rear is not expected for an $\mathrm{Al}_{2} \mathrm{O}_{3}$-rear-passivated cell. In combination with its very high transparency for near-bandgap photons, ALD-deposited $\mathrm{Al}_{2} \mathrm{O}_{3}$ should hence be an optimal choice for a dielectric layer at the silicon solar cell rear.

In addition to the outstanding surface passivation provided by $\mathrm{ALD}$-deposited $\mathrm{Al}_{2} \mathrm{O}_{3}$, the deposition process itself is also beneficial from an application point of view. In contrast to the conventionally applied PECVD, ALD consists of two self-limiting half-reactions, which implies several important advantages: (1) ALD gives highly conformal coatings, which allows to deposit and passivate, e.g., deep trenches or even pores in silicon, (2) pin-hole and particle-free deposition is achieved, (3) as ALD is a selflimiting process, uniform films can be deposited over large areas with mono-layer growth control, and (4) very low impurity concentrations of deposited films and hence very high film quality is achieved.

The main disadvantage of ALD for photovoltaic applications is its relatively low deposition rate. However, this disadvantage can be overcome by depositing ultrathin $(2-30 \mathrm{~nm}) \mathrm{ALD}-\mathrm{Al}_{2} \mathrm{O}_{3}$ films and capping them with a thicker film of, e.g., PECVD-SiO $x, \mathrm{SiN}_{x}$ or $\mathrm{SiC}_{x}$ [80]. Apart of the advantageous optical properties of these stacks, the passivation quality of such ALD/PECVD stacks can even be superior to that of single layers of $\mathrm{Al}_{2} \mathrm{O}_{3}$, which could be attributed to the hydrogenation of interface states at the $\mathrm{Al}_{2} \mathrm{O}_{3} / \mathrm{Si}$ interface during deposition of the hydrogen-rich PECVD layer [28]. Combination of ALD and PECVD might hence be a key technology for future industrial highefficiency solar cells. 
Table 2 Surface passivation methods of c-Si solar cells that were developed in the past 30 years

\begin{tabular}{|c|c|c|c|}
\hline Cell concepts/types & Types of passivation used & Remarks & Efficiency (\%) \\
\hline Screen-printed cells & $\mathrm{p}-\mathrm{n}$ junction passivation & $\begin{array}{l}\text { Larger shading loss, poor blue response, } \\
\text { modest short-circuits currents }\end{array}$ & $15-16$ \\
\hline Buried-contact cells & Thermal oxide passivation & Reduced shading loss by $50 \%$ & $17-18$ \\
\hline PERL/LBSF cells & Thermal oxide passivation & Lower surface recombination & 24.7 \\
\hline $\begin{array}{l}\text { Backside-contact } \\
\text { concentrator solar cells }\end{array}$ & Thermal oxide passivation & $\begin{array}{l}\text { Eliminate metal shading loss, facilitating } \\
\text { the interconnection of individual cells }\end{array}$ & $22.7-26$ \\
\hline Bifacial cells & Silicon nitride passivation & $\begin{array}{l}\text { Both surfaces of the cell are passivated, } \\
\text { minimize reflection losses, etc }\end{array}$ & $18.1-20.1$ \\
\hline MIS inversion-layer cells & Silicon nitride passivation & $\begin{array}{l}\text { Low temperature treatment, promising } \\
\text { candidates for cost-effective generation } \\
\text { of PV electricity }\end{array}$ & 18.5 \\
\hline HIT cells & Double-layer stack of a-Si & $\begin{array}{l}\text { Low SRV, junction is formed at only } \\
200{ }^{\circ} \mathrm{C}\end{array}$ & 20.0 \\
\hline $\begin{array}{l}\text { Thin-film polycrystalline } \\
\text { silicon cells }\end{array}$ & $\begin{array}{l}\text { PECVD deposited silicon } \\
\text { of only } 2 \mu \mathrm{m}\end{array}$ & Very thin & 10.1 \\
\hline
\end{tabular}

Efficiencies shown in the table are the theoretical limit

Aggregated results of efficiencies of different cell types after exploiting different passivation schemes are shown in Table 2.

\section{Conclusions}

Solar cells made from crystalline silicon have lower conversion efficiency and hence optimization of each process step is very important. Increasing the efficiency of crystalline silicon solar cells relies on the understanding and optimization of each individual processing step as well as of the interplay between the material properties and the processing conditions. Our focus was to review the advances in existing surface passivation techniques in an industrial process line as well as in the research laboratories over the world. Every c-Si solar cell fabricated to date features one or more of these surface passivation methods. With regard to solar cell applications, it is important to make sure that the surface passivation is long-term stable ( $>20$ years) and stable against the UV photons of sunlight.

In order to increase the efficiency of silicon-wafer-based solar cells in production well above $20 \%$, it is indispensable to improve the currently applied level of surface passivation at the front as well as at the rear of the cells. In the past, low surface recombination velocities $(<20 \mathrm{~cm} / \mathrm{s})$ have been achieved on low-resistivity $(\sim 1 \Omega \mathrm{cm})$ p-type silicon using plasma-enhanced chemical-vapor-deposited (PECVD) silicon nitride $\left(\mathrm{SiN}_{x}\right)$ as well as amorphous silicon (a-Si). However, the high density of fixed positive

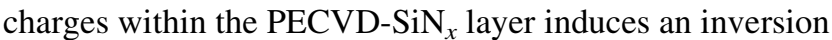
layer at the rear of p-type Si cells, producing a detrimental parasitic shunting, which reduces the short-circuit current density by up to $3 \mathrm{~mA} / \mathrm{cm}^{2}$. The passivation quality of a-Si, on the other hand, is very temperature sensitive. More recently it has been shown that atomic-layer-deposited (ALD) aluminum oxide $\left(\mathrm{Al}_{2} \mathrm{O}_{3}\right)$ provides an outstanding level of surface passivation, which can be attributed to its extremely high negative fixed charge density in combination with the very gentle deposition technique ALD, leading to low interface state densities. The application of these ALD- $\mathrm{Al}_{2} \mathrm{O}_{3}$ layers to the rear of p-type solar cells shows that this new passivation scheme is indeed suitable for high efficiencies and that due to the large negative fixed charge density no parasitic shunting occurs. In a direct comparison with other passivation schemes, it is found that $\mathrm{Al}_{2} \mathrm{O}_{3}$ even outperforms optimized thermally grown $\mathrm{SiO}_{2}$ and opens the possibility of achieving very large opencircuit voltages up to $V_{\mathrm{oc}}=740 \mathrm{mV}$.

However, whenever a particular process is required to be optimized, the amount of extra steps should be kept to an absolute minimum and ideally the general cell line concept should not be changed drastically to make the approach cost-effective and easy to implement.

Open Access This article is distributed under the terms of the Creative Commons Attribution License which permits any use, distribution, and reproduction in any medium, provided the original author(s) and the source are credited.

\section{References}

1. Hall, R.: Electron-hole recombination in germanium. Phys. Rev. 87, 387 (1952)

2. Shockley, W., Read, W.: Statistics of the recombinations of holes and electrons. Phys. Rev. 87, 835-842 (1952) 
3. Aberle, A.: Crystalline Silicon Solar Cells: Advanced Surface Passivation and Analysis. Centre for Photovoltaic Engineering, University of NSW, Australia (1999)

4. http://www.iea.org

5. Seiffe, J., Hofmann, M., Rentsch, J., Preu, R.: Charge carrier trapping at passivated silicon surfaces. J. Appl. Phys. 109, 064505 (2011)

6. Röder, T., Eisele, S., Grabitz, P., Wagner, C., Kulushich, G., Köhler, J., Werner, J.: Add-on laser tailored selective emitter solar cells. Prog. Photovolt. Res. Appl. 18, 505-510 (2010)

7. Queisser, H.J., Haller, E.E.: Defects in semiconductors: some fatal, some vital. Science 281, 945-950 (1998)

8. Boroditsky, M., Gontijo, I., Jackson, M., Vrijen, R., Yablonovitch, E., Krauss, T., Cheng, C.C., Scherer, A., Bhat, R., Krames, M.: Surface recombination measurements on III-V candidate materials for nanostructure light-emitting diodes. J. Appl. Phys. 87, 3497 (2000)

9. Jin, H., Weber, K.J., Dang, N.C., Jellett, W.E.: Defect generation at the $\mathrm{Si}-\mathrm{SiO}_{2}$ interface following corona charging. Appl. Phys. Lett. 90, 262109 (2007)

10. Hoex, B., Gielis, J.J.H., van de Sanden, M.C.M., Kessels, W.M.M.: On the c-Si surface passivation mechanism by the negative-charge-dielectric $\mathrm{Al}_{2} \mathrm{O}_{3}$. J. Appl. Phys. 104, 113703 (2008)

11. Rein, S.: Lifetime Spectroscopy: A Method of Defect Characterization in Silicon for Photovoltaic Applications. Springer, Berlin (2004)

12. Aberle, A.: Surface passivation of crystalline silicon solar cells: a review. Prog. Photovolt. Res. Appl. 8, 473-487 (2000)

13. Hoex, B., Heil, S., Langereis, E., Sanden, M., Kessels, W.: Ultralow surface recombination of $\mathrm{c}-\mathrm{Si}$ substrate passivated by plasma-assisted atomic layer deposited $\mathrm{Al}_{2} \mathrm{O}_{3}$. Appl. Phys. Lett. 89, 1-3 (2006)

14. Lauinger, T., Schmidt, J., Aberle, A.G., Hezel, R.: Record low surface recombination velocities on $1 \mathrm{ohm}-\mathrm{cm}$ p-silicon using remote plasma silicon nitride passivation. Appl. Phys. Lett. 68, 1232-1234 (1996)

15. Leguijt, C., Lölgen, P., Eikelboom, J.A., Weeber, A.W., Schuurmans, F.M., Sinke, W.C., Alkemade, P.F.A., Sarro, P.M., Marée, C.H.M., Verhoef, L.A.: Solar energy materials. Solar Cells 40, 297-345 (1996)

16. Nagel, H., Aberle, A., Hezel, R.: Optimisedantireflection coatings for planar silicon solar cells using remote PECVD silicon nitride and poroud silicon dioxide. Prog. Photovolt. Res. Appl. 17, 245-260 (1999)

17. Kimura, K.: Recent developments in polycrystalline silicon solar cells. In: Proceedings of the 1st International Photovoltaic Science and Engineering Conference, Kobe, Japan, pp. 37-42, 13-16 November 1984

18. Stocks, M., Cuevas, A., Blakers, A.: Minority carrier lifetimes of multicrystalline silicon during solar cell processing. In: Proceedings of the 14th European Photovoltaic Solar Energy Conference, Barcelona, Spain, pp. 770-773, 30 June-4 July 1997

19. Agostinelli, G., Delabie, A., Vitanov, P., Alexieva, Z., Dekkers, H.F.W., De Wolf, S., Beaucarne, G.: Very low surface recombination velocities on p-type silicon wafers passivated with a dielectric with fixed negative charge. Sol. Energy Mater. Sol. Cells 90, 3438 (2006)

20. Hoex, B., Heil, S.B.S., Langereis, E., van de Sanden, M.C.M., Kessels, W.M.M.: Ultralow surface recombination of c-Si substrate passivated by plasma-assisted atomic layer deposited $\mathrm{Al}_{2} \mathrm{O}_{3}$. Appl. Phys. Lett. 89, 042112 (2006)

21. Hoex, B., Schmidt, J., Bock, R., Altermatt, P.P., van de Sanden, M.C.M., Kessels, W.M.M.: Excellent passivation of highly doped p-type $\mathrm{Si}$ surfaces by the negative-charge-dielectric $\mathrm{Al}_{2} \mathrm{O}_{3}$. Appl. Phys. Lett. 91, 112107 (2007)
22. Hoex, B., Schmidt, J., Pohl, P., van de Sanden, M.C.M., Kessels, W.M.M.: Silicon surface passivation by atomic layer deposited $\mathrm{Al}_{2} \mathrm{O}_{3}$. J. Appl. Phys. 104, 044903 (2008)

23. Schmidt, J., Merkle, A., Brendel, R., Hoex, B., van de Sanden, M.C.M., Kessels, W.M.M.: Surface passivation of high efficiency solar cells by atomic layer deposited $\mathrm{Al}_{2} \mathrm{O}_{3}$. Prog. Photovolt. 16, 461 (2008)

24. Benick, J., Hoex, B., van de Sanden, M.C.M., Kessels, W.M.M., Schultz, O., Glunz, S.: High efficiency n-type Si solar cells on $\mathrm{Al}_{2} \mathrm{O}_{3}$-passivated boron emitters. Appl. Phys. Lett. 92, 253504 (2008)

25. Chen, M.J., Shih, Y.T., Wu, M.K., Tsai, F.Y.: Enhancement in the efficiency of light emission from silicon by a thin $\mathrm{Al}_{2} \mathrm{O}_{3}$ surface-passivating layer grown by atomic layer deposition at low temperature. J. Appl. Phys. 101, 033130 (2007)

26. Dingemans, G., Kessels, W.M.M.: Recent progress in the development and understanding of silicon surface passivation by aluminum oxide for photovoltaics. In: Proceedings of the 25th European Photovoltaic Solar Energy Conference, Valencia, Spain (2010)

27. Grant, N.E., McIntosh, K.R.: Silicon surface by silicon dioxide grown in nitric acid. IEEE Electron Device Lett. 30, 922 (2009)

28. Schmidt, J., Merkle, A., Brendel, R., Hoex, B., Sanden, M., Kessels, W.: Surface passivation of high efficiency solar cells by atomic layer deposited $\mathrm{Al}_{2} \mathrm{O}_{3}$. Prog. Photovolt. Res. Appl. 16, 461-466 (2008)

29. Dingemans, G., van de Sanden, M.C.M., Kessels, W.M.M.: Excellent $\mathrm{Si}$ surface passivation by low temperature $\mathrm{SiO}_{2}$ using an ultrathin $\mathrm{Al}_{2} \mathrm{O}_{3}$ capping film. Phys. Status Solidi RRL 5(1), 22-24 (2011). doi:10.1002/pssr.201004378

30. Saint-Cast, P., Benick, J., Kania, D., Weiss, L., Hofmann, M., Rentsch, J., Preu, R., Glunz, S.W.: High-efficiency c-Si solar cells passivated with ALD and PECVD aluminum oxide. IEEE Elec. Dev. Lett. 31(7), 695-697 (2010)

31. Dingemans, G., et al.: Hydrogen induced passivation of $\mathrm{Si}$ interfaces by $\mathrm{Al}_{2} \mathrm{O}_{3}$ films and $\mathrm{SiO}_{2} / \mathrm{Al}_{2} \mathrm{O}_{3}$ stacks. Appl. Phys. Lett. 97, 152106 (2010)

32. Dauwe, S., Mittelstädt, L., Metz, A., Hezel, R.: Experimental evidence of parasitic shunting in silicon nitride rear surface passivated solar cells. Prog. Photovolt. Res. Appl. 10, 271-278 (2002)

33. Saint-Cast, P., Kania, D., Hofmann, M., Benick, J., Rentsch, J., Preu, R.: Very low surface recombination velocity on p-type c-Si by high-rate plasma-deposited aluminum oxide. Appl. Phys. Lett. 95, 151502 (2009)

34. Dingemans, G., van de Sanden, M.C.M., Kessels, W.M.M.: Influence of the deposition temperature on the c-Si surface passivation by $\mathrm{Al}_{2} \mathrm{O}_{3}$ films synthesized by ALD and PECVD. Electrochem. Solid-State Lett. 13, H76 (2009)

35. Werner, F., Veith, B., Zielke, D., Kühnemund, L., Tegenkamp, C., Seibt, M., Brendel, R., Schmidt, J.: Electronic and chemical properties of the c-Si/ $/ \mathrm{Al}_{2} \mathrm{O}_{3}$ interface. J. Appl. Phys. 109, 113701 (2011)

36. Matsunaga, K., Tanaka, T., Yamamoto, T., Ikuhara, Y.: Firstprinciples calculations of intrinsic defects in $\mathrm{Al}_{2} \mathrm{O}_{3}$. Phys. Rev. B 68, 085110 (2003)

37. Peacock, P.W., Robertson, J.: Behavior of hydrogen in high dielectric constant oxide gate insulators. Appl. Phys. Lett. 83, 2025 (2003)

38. Lucovsky, G.: A chemical bonding model for the native oxides of the III-V compound semiconductors. J. Vac. Sci. Technol. 19, 456 (1981)

39. Kimoto, K., Matsui, Y., Nabatame, T., Yasuda, T., Mizoguchi, T., Tanaka, I., Toriumi, A.: Coordination and interface analysis of atomic-layer-deposition $\mathrm{Al}_{2} \mathrm{O}_{3}$ on $\mathrm{Si}(001)$ using energy-loss nearedge structures. Appl. Phys. Lett. 83, 4306 (2003) 
40. Aboaf, J.A., Kerr, D.R., Bassous, E.: Charge in $\mathrm{SiO}_{2}-\mathrm{Al}_{2} \mathrm{O}_{3}$ double layers on silicon. J. Electrochem. Soc. 120, 1103 (1973)

41. Johnson, R.S., Lucovsky, G., Baumvol, I.: Physical and electrical properties of noncrystalline $\mathrm{Al}_{2} \mathrm{O}_{3}$ prepared by remote plasma enhanced chemical vapor deposition. J. Vac. Sci. Technol. A 19, $1353(2001)$

42. No, S.Y., Eom, D., Hwang, C.S., Kim, H.J.: Property changes of aluminum oxide thin films deposited by atomic layer deposition under photon radiation. J. Electrochem. Soc. 153, F87 (2006)

43. Gielis, J.J.H., Hoex, B., van de Sanden, M.C.M., Kessels, W.M.M.: Negative charge and charging dynamics in $\mathrm{Al}_{2} \mathrm{O}_{3}$ films on Si characterized by second-harmonic generation. J. Appl. Phys. 104, 073701 (2008)

44. Dingemans, G., et al.: Firing stability of atomic layer deposited $\mathrm{Al}_{2} \mathrm{O}_{3}$ for $\mathrm{c}-\mathrm{Si}$ surface passivation. In: Proceedings of the 34th IEEE Photovoltaics Specialists Conference, Philadelphia, USA (2009)

45. Schmidt, J., et al.: Progress in the surface passivation of silicon solar cells. In: Proceedings of the 23rd European Photovoltaic Solar Energy Conference, Valencia, Spain (2008)

46. Dingemans, G., Seguin, R., Engelhart, P., Einsele, F., Hoex, B., van de Sanden, M.C.M., Kessels, W.M.M.: Stability of $\mathrm{Al}_{2} \mathrm{O}_{3}$ and $\mathrm{Al}_{2} \mathrm{O}_{3} / \mathrm{a}-\mathrm{SiNx}: \mathrm{H}$ stacks for surface passivation of crystalline silicon. J. Appl. Phys. 106, 114907 (2009)

47. Dingemans, G., Seguin, R., Engelhart, P., van de Sanden, M.C.M., Kessels, W.M.M.: Silicon surface passivation by ultrathin $\mathrm{Al}_{2} \mathrm{O}_{3}$ films synthesized by thermal and plasma atomic layer deposition. Phys. Status Solidi RRL 4, 10 (2010)

48. Terlinden, N.M., et al.: Role of field-effect on c-Si surface passivation by ultrathin $(2-20 \mathrm{~nm})$ atomic layer deposited $\mathrm{Al}_{2} \mathrm{O}_{3}$. Appl. Phys. Lett. 96, 112101 (2010)

49. Dingemans, G., Engelhart, P., Seguin, R., Mandoc, M.M., van de Sanden, M.C.M., Kessels, W.M.M.: Comparison between $\mathrm{Al}_{2} \mathrm{O}_{3}$ surface passivation films deposited with thermal ALD, plasma ALD and PECVD. In: 35th IEEE PVSC, Honolulu, Hawaii, 20-25 June 2010

50. Stocks, M., Cuevas, A.: Surface recombination velocity of thermally oxidized multicrystalline silicon. In: Proceedings of the 2nd World Conference on Photovoltaic Energy Conversion, Vienna, Austria, pp. 1623-1626, 6-10 July 1998

51. Schultz, O., Mette, A., Hermle, M., Glunz, S.: Thermal oxidation for crystalline silicon solar cells exceeding $19 \%$ efficiency applying industrially feasible process technology. Prog. Photovolt. Res. Appl. 16, 317-324 (2008)

52. Catchpole, K., Blakers, A.: Modelling of the PERC structure with strip and dot back contacts. In: Proceedings of the 16th European Photovoltaic Solar Energy Conference, Glasgow, UK, pp. 1719-1722, 1-5 May 2000

53. Benick, J., Zimmermann, K., Spiegelman, J., Hermle, M., Glunz, S.W.: Rear side passivation of PERC-type solar cells by wet oxides grown from purified steam. Prog. Photovolt. Res. Appl. 19, 361-365 (2011)

54. Schultz, O., Glunz, S., Goldschmidt, J., Lautenschlager, H., Leimenstoll, A., Schneiderlöchner, E., Willeke, G.: Thermal oxidation processes for high efficiency multicrystalline silicon solar cells. In: Proceedings of the 19th European Photovoltaic Solar Energy Conference, Paris, France, pp. 604-607, 7-11 June 2004

55. Seiffe, J, Gautero, L, Hofmann, M, Rentsch, J, Preu, R, Weber, S, Eichel, R.A.: Surface passivation of crystalline silicon by plasmaenhanced chemical vapor deposition double layers of silicon-rich silicon oxynitride and silicon nitride. J. Appl. Phys. 109, 034105 (2011)

56. Dingemans, G., Mandoc, M.M., Bordihn, S., van de Sanden, M.C.M., Kessels, W.M.M.: Effective passivation of Si surfaces by plasma deposited $\mathrm{SiO}_{\mathrm{x}} / \mathrm{a}-\mathrm{SiN}_{\mathrm{x}}: \mathrm{H}$ stacks. Appl. Phys. Lett. 98, $222102(2011)$
57. Hofmann, M., Schmidt, C., Kohn, N., Rentsch, J., Glunz, S.W., Preu, R.: Stack system of PECVD amorphous silicon and PECVD silicon dioxide for silicon solar cell rear side passivation. Prog. Photovolt. Res. Appl. 16, 509-518 (2008)

58. Glunz, S., Grohe, A., Hermle, M., Hofmann, M., Janz, S., Roth, T., Schultz, O., Vetter, M., Martin, I., Ferré, R., Bermejo, S., Wolke, W., Warta, W., Preu, R., Willeke, G.: Comparison of different dielectric layers for application in industrially feasible high-efficiency crystalline silicon solar cells. In: Proceedings of the 20th European Photovoltaic Solar Energy Conference, Barcelona, Spain, pp. 572-577, 6-10 June 2005

59. Martín, I., Vetter, M., Orpella, A., Voz, C., Puigdollers, J., Alcubilla, R.: Characterization of p-type c-si surface passivation by $\mathrm{n}$-doped $\mathrm{a}-\mathrm{SiC}_{\mathrm{x}}: \mathrm{H}$ films In: Proceedings of the 17th European Photovoltaic Solar Energy Conference, Munich, Germany, pp. 2954-2957, 22-26 October 2001

60. Ferre, R., Martín, I., Vetter, M., Garín, M., Alcubilla, R.: Effect of amorphous silicon carbide layer thickness on the passivation quality of crystalline silicon surface. Appl. Phys. Lett. 87, 202109-202111 (2005)

61. Janz, S., Riepe, S., Hofmann, M., Reber, S., Glunz, S.: Phosphorous-doped $\mathrm{SiC}$ as an excellent p-type $\mathrm{Si}$ surface passivation layer. Appl. Phys. Lett. 88, 133516-133517 (2006)

62. Martín, I., Vetter, M., Orpella, A., Puigdollers, J., Cuevas, A., Alcubilla, R.: Surface passivation of p-type crystalline Si by plasma enhanced chemical vapor deposited amorphous $\mathrm{SiC}_{\mathrm{x}}: \mathrm{H}$ films. Appl. Phys. Lett. 79, 2199-2201 (2001)

63. Ferre R, Martín, I., Ortega, P., Vetter, M., Torres, I., Alcubilla, R.: n-Type emitter surface passivation in $\mathrm{c}-\mathrm{Si}$ solar cells by means of antireflective amorphous silicon carbide layers. J. Appl. Phys. 100, 073703-073710 (2006)

64. Folsch, J., Robel, H., Schade, H.: Change in bonding properties of amorphous hydrogenated silicon-carbide layers prepared with different gases as carbon sources. Appl. Phys. Lett. 61, 3029-3031 (1992)

65. Street, R.A.: Hydrogen chemical potential and structure of a-Si:H. Phys. Rev. B. 43, 2454-2457 (1991)

66. Ehling, C., Bilger, G., Schubert, M.B.: Thermally stable a-Si1$\mathrm{xCx}: \mathrm{H}$ passivation layers. In: Proc. 24th European Photovoltaic Solar Energy Conference, Germany, 2009

67. Langford, A.A., Fleet, M.L., Nelson, B.P., Lanford, W.A., Maley, N.: Infrared absorption strength and hydrogen content of hydrogenated amorphous silicon. Phys. Rev. B. 45, 13367-13377 (1992)

68. Iqbal, Z., Vepfek, S.: Raman scattering from hydrogenated microcrystalline and amorphous silicon. J. Phys. C Solid State Phys. 15, 377-392 (1982)

69. Gall, S., Muske, M., Sieber, S., Nast, O., Fuhs, W.: Aluminuminduced crystallization of amorphous silicon. J. Non Cryst. Solids 299, 741-745 (2002)

70. Ferre, R., Orpella, A., Munoz, D., Martín, I., Recart, F., Voz, C., Puigdollers, J., Cabarrocas, P., Alcubilla, R.: Very low surface recombination velocity of crystalline silicon passivated by phosphorus-doped a-SiC $\mathrm{N}_{\mathrm{y}}: \mathrm{H}(\mathrm{n})$ alloys. Prog. Photovolt. Res. Appl. 16, 123-127 (2008)

71. Lauermann, T., Lüder, T., Scholz, S., Raabe, B., Hahn, G., Terheiden, B.: Enabling dielectric rear side passivation for industrial mass production by developing lean printing based solar cell processes. In: 35th IEEE PVSC, Honolulu, 20-25 June 2010

72. Dingemans, G., Engelhart, P., Seguin, R., Einsele, F., Hoex, B., van de Sanden, M.C.M., Kessels, W.M.M.: Stability of $\mathrm{Al}_{2} \mathrm{O}_{3}$ and $\mathrm{Al}_{2} \mathrm{O}_{3} / \mathrm{a}-\mathrm{SiN}_{\mathrm{x}}: \mathrm{H}$ stacks for surface passivation of crystalline silicon. J. Appl. Phys. 106, 114907 (2009)

73. Schmidt, J., Moschner, J.D., Henze, J., Dauwe, S., Hezel, R.: Proc. 19th EUPVSEC, Paris, France, p. 391 (2004)

74. Dauwe, S., Mittelstädt, L., Metz, A., Schmidt, J., Hezel, R.: Lowtemperature rear surface passivation schemes for $>20 \%$ efficient 
silicon solar cells. In: Proceedings of the 3rd WCPEC, Osaka, Japan, p. 1395 (2003)

75. Dauwe, S., Schmidt, J., Hezel, R.: Very low surface recombination velocities on $\mathrm{p}$ - and n-type silicon wafers passivated with hydrogenated amorphous silicon films. In: Proceedings of the 29th IEEE PVSEC, New Orleans, USA, pp. 1246-1249 (2002)

76. Agostinelli, G., Delabie, A., Vitanov, P., Alexieva, Z., Dekkers, H.F.W., De Wolf, S., Beaucarne, G.: Very low surface recombination velocities on p-type silicon wafers passivated with a dielectric with fixed negative charge. Sol. En. Mat. Sol. Cells 90, 3438 (2006)

77. Hoex, B., Schmidt, J., Bock, R., Altermatt, P.P., van de Sanden, M.C.M., Kessels, W.M.M.: Excellent passivation of highly doped p-type $\mathrm{Si}$ surfaces by the negative-charge-dielectric $\mathrm{Al}_{2} \mathrm{O}_{3}$. Appl. Phys. Lett. 91, 112107 (2007)

78. Dauwe, S.: Low-temperature rear surface passivation of crystalline silicon solar cells.Ph.D. thesis, ISFH, University of Hanover, Germany (2003)

79. Hoex, B., Schmidt, J., Pohl, P., van de Sanden, M.C.M., Kessels, W.M.M.: Silicon surface passivation by atomic layer deposited $\mathrm{Al}_{2} \mathrm{O}_{3}$. J. Appl. Phys. 104, 044903 (2008)

80. Schmidt, J., Merkle, A., Hoex, B., van de Sanden, M.C.M., Kessels, W.M.M., Brendel, R.: Atomic-layer-deposited aluminium oxide for the surface passivation of high-efficiency silicon solar cells. In: Proceedings of the 33rd IEEE PVSC, San Diego, USA (2008) 